\title{
KURANG ASUPAN VITAMIN A, C, E DAN BETA KAROTEN MENINGKATKAN KEJADIAN PREEKLAMPSIA DI RSUP DR. SARDJITO, YOGYAKARTA
}

\author{
Nofrisa Mutia P1; T. Ninuk Sri Hartini2,3; dan Mohammad Hakimi 3,4 \\ ${ }^{1}$ Fakultas Kedokteran, Universitas Gadjah Mada (UGM), DIY \\ 2Jurusan Gizi, Politeknik Kementerian Kesehatan RI, DIY \\ ${ }^{3}$ Laboratorium Penelitian Kesehatan dan Gizi Masyarakat (LPK-GM), FK-UGM, DIY \\ ${ }^{4}$ Bagian Obstetri dan Ginekologi, Fakultas Kedokteran, UGM, DIY
}

\begin{abstract}
The Objective of this study was to evaluate the vitamin A, C, E and beta carotene intakes and preeclampsia among pregnant women. The data were analyzed from 30 pregnant women with preeclampsia as a case group and 30 healthy pregnant women as a control group. The survey was carried out between July 2004 and February 2005 at Sardjito Hospital, Yogyakarta. The nutrient intakes are presented as median values and the Kruskal-Wallis test and the Mann-Whitney $U$ test were used. Multiple linear regression models were used to examine the factors associated with preeclampsia. In total, 23 percent pregnant women craved foods, 40 percent avoided certain foods, 23 percent had consumed jamu during pregnancy and $68 \%$ were consuming iron supplements. The percentage of healthy pregnant women consumed iron supplements was higher than pregnant women with preeclampsia $(p<0.05)$. In contrast, the percentage of healthy pregnant women consumed jamu was lower than pregnant women with preeclampsia $(p<0.05)$. Healthy pregnant women had higher vitamin $A, C, E$ and beta carotene intakes than pregnant women with preeclampsia. There were no significant differences among those groups. Pregnant women consuming low vitamin A, C, E and beta carotene intake are at risk of developing preeclampsia.
\end{abstract}

Keywords: pregnant women, preeclampsia, vitamin A, C, E and beta carotene intake

\section{PENDAHULUAN}

$\mathrm{D}$ negara berkembang, preeklampsia merupakan salah satu penyebab kematian utama pada wanita selama kehamilan. Angka kejadian preeklampsia 2-10 persen dari seluruh angka kehamilan ${ }^{1}$ dan angka kejadian preeklampsia pada multipara sebesar 6-7 persen².

Preeklampsia merupakan salah satu komplikasi kehamilan yang ditandai dengan meningkatnya tekanan darah, terdapatnya protein dalam urine, dan atau terjadinya oedema $^{3}$. Tekanan diastolik pada penderita preeklampsia mencapai $90 \mathrm{mmHg}$ atau lebih, proteinuria $\geq 300 \mathrm{mg}$ dalam 24 jam, dan kreatinin urin $\geq 30 \mathrm{mg} / \mathrm{mmol}$ pada sampel urine acak. Trias ini biasanya muncul setelah usia kehamilan 20 minggu $^{4}$. Gejala lain yang dapat menyertai preeklampsia adalah: nyeri pada epigastrium, gangguan penglihatan, dan sakit kepala 5 .

Faktor resiko preeklampsia dapat meningkat pada wanita dengan kehamilan ganda (gemelli), penyakit ginjal dan vaskuler, penyakit diabetes, riwayat preeklampsia pada kehamilan sebelumnya, serta antibodi anti- fosfolipid ${ }^{6}$. Faktor lain yang juga dapat mempengaruhi kejadian preeklampsia yakni: obesitas, faktor angiotensinogen T235, mutasi faktor $V$ leiden, usia ibu yang lebih dari 35 tahun dan kurang dari 15 tahun 7 .

Beberapa faktor predisposisi yang dapat menyebabkan preeklampsia antara lain kurangnya perfusi plasenta, pertumbuhan plasenta yang abnormal, konsentrasi homosistein yang tinggi, stress oksidatif serta faktor genetik ${ }^{8}$. Meskipun faktor-faktor yang berpengaruh terhadap preeklampsia telah diketahui, namun hingga saat ini patogenesis maupun etiologi preeklampsia masih belum jelas. Dua kunci utama yang berperan dalam patogenesis preeklampsia adalah invasi sitotrotrofoblas endovaskuler pada arteri spiralis dan disfungsi sel endothel ${ }^{9}$.

Salah satu penyebab yang mampu mengakibatkan kerusakan endothel adalah stres oksidatif. Stres oksidatif terjadi apabila konsentrasi radikal bebas di dalam tubuh melebihi kapasitas antioksidan atau berkurangnya kadar antioksidan di dalam tubuh ${ }^{10}$.

Radikal bebas yang merusak lipid dan protein sel, dapat menyebabkan preeklampsia. 
Beberapa contoh radikal bebas yaitu superoksida, peroksida, dan nitrogen reaktif serta nitrit oksida. Radikal bebas dapat diterapi dengan pemberian antioksidan seperti vitamin A, C, E, serta beta karoten, superoksida dismutase, antioksidan lipid, dan glutation peroksidase serta selenium ${ }^{11}$.

Vitamin A, C, E serta beta karoten banyak terdapat dalam sayuran serta buah-buahan yang dikonsumsi. Kurangnya asupan vitamin $\mathrm{A}$, C, E serta beta karoten dapat menyebabkan ketidakseimbangan antara radikal bebas dan antioksidan dalam tubuh ${ }^{12}$. Berdasarkan hasil penelitian sebelumnya tentang peran anti oksidan terhadap radikal bebas dalam tubuh, perlu adanya penelitian tentang hubungan asupan vitamin $A, C, E$ dan beta karoten dengan preeklampsia.

\section{METODE PENELITIAN}

Rancangan penelitian yang digunakan adalah studi kasus (case control). Sampel berjumlah 30 orang ibu menderita preeklampsia dan 30 orang ibu sehat sebagai kelompok kontrol. Kedua kelompok tersebut melahirkan dan dirawat di bagian Obstetri Ginekologi RSUP dr.Sardjito bulan Juli 2004 sampai dengan bulan Februari 2005 dengan matching umur dan paritas. Kriteria inklusi adalah wanita hamil, janin hidup, serta bersedia menandatangani informed consent. Kriteria eksklusi mencakup gemelli (kehamilan kembar), hipertensi kronis serta menderita penyakit berat seperti gagal jantung, dan gagal ginjal.

Data asupan vitamin A, C, E, dan beta karoten dikumpulkan melalui wawancara individu dengan metode riwayat makan (dietary history) selama trimester 1 dan 2. Wawancara dilakukan selama pasien postpartum dirawat di Rumah Sakit Dr. Sardjito. Daftar makanan yang tercantum dalam daftar pertanyaan berasal dari penelitian Morvita, Dietvita dan Zibuvita ${ }^{13,14,15}$. Makanan yang dicantumkan dalam kuesioner terdiri dari makanan pokok, lauk hewani, lauk nabati, sayur-sayuran, buah-buahan, minyak goreng, jamu, suplemen zat besi dan data pantangan makan, serta ngidam.

Banyaknya makanan yang dikonsumsi dinyatakan dalam porsi seperti potong, piring, mangkuk, gelas, sendok makan, sendok teh. Data asupan makanan diterjemahkan ke asupan zat gizi menggunakan Inafood program $13,14,15$. Rumus yang digunakan untuk menterjemahkan banyaknya makanan yang dikonsumsi ke asupan vitamin $A, C, E$ dan beta karoten per orang per hari sebagai berikut:

\section{Asupan zat gizi perhari = kandungan zat gizi x banyaknya makanan $\mathrm{x}$ frekuensi makan}

\section{Hari makan}

Data diuji dengan Mann-Whitney test. Analisis Mann-Whitney dilakukan untuk mengetahui perbedaan asupan vitamin $A, C, E$, dan beta karoten pada kelompok ibu hamil yang menderita preeklampsia dan ibu hamil yang sehat. Data dianalisis menggunakan komputer. Tingkat kepercayaan 95 persen.

\section{HASIL}

\section{Karakteristik responden}

Rerata usia ibu adalah $30 \pm 5,9$ tahun, paling muda berusia 19 tahun dan paling tua 44 tahun. Sejumlah 65 persen ibu adalah multigravida. Ibu yang memiliki riwayat hipertensi pada kehamilan sebelumnya berjumlah 8,3 persen dan 1,7 persen ibu mempunyai riwayat hipertensi sebelum hamil.

\section{Pantangan terhadap makanan, konsumsi jamu dan suplemen}

Dari Tabel 1 terlihat bahwa 23 persen dan 40 persen dari 60 orang ibu hamil mengalami ngidam dan memantang makanan tertentu selama hamil. Persentase ibu hamil sehat yang mengalami ngidam dan pantang makan lebih tinggi dibanding ibu hamil yang menderita preeklampsia dan perbedaan tersebut tidak bermakna. Dari 60 ibu hamil, ternyata 23 persen mengkonsumsi jamu dan 68 persen mengkonsumsi suplemen besi selama hamil. Persentase ibu dengan preeklampsia lebih tinggi mengkonsumsi jamu daripada ibu dengan kehamilan sehat $(p<0,05)$. Sebaliknya, persentase penggunaan suplemen besi sedikit lebih tinggi pada ibu dengan kehamilan sehat $(p<0,05)$. 
Tabel 1

Frekuensi Ngidam, Pantangan Makan, Konsumsi Jamu dan Suplemen yang Dikonsumsi lbu Hamil

\begin{tabular}{|c|c|c|c|c|c|c|c|c|c|c|c|c|}
\hline \multirow{3}{*}{ Pola konsumsi } & \multicolumn{4}{|c|}{ Ibu hamil preeklamsi } & \multicolumn{4}{|c|}{ Ibu hamil normal } & \multicolumn{4}{|c|}{ Jumlah } \\
\hline & \multicolumn{2}{|c|}{$\mathrm{Ya}$} & \multicolumn{2}{|c|}{ Tidak } & \multicolumn{2}{|c|}{$\mathrm{Ya}$} & \multicolumn{2}{|c|}{ Tidak } & \multicolumn{2}{|c|}{$\mathrm{Ya}$} & \multicolumn{2}{|c|}{ Tidak } \\
\hline & $\mathrm{n}$ & $\%$ & $\mathrm{n}$ & $\%$ & $\mathrm{n}$ & $\%$ & $\mathrm{n}$ & $\%$ & $\mathrm{n}$ & $\%$ & $\mathrm{n}$ & $\%$ \\
\hline Ngidam & 6 & 20 & 24 & 80 & 8 & 27 & 22 & 73 & 14 & 23 & 46 & 77 \\
\hline Pantang makan & 18 & 60 & 12 & 40 & 5 & 70 & 2 & 30 & 24 & 40 & 36 & 60 \\
\hline Konsumsi jamu** & 9 & 30 & 21 & 70 & 5 & 17 & 25 & 83 & 14 & 23 & 46 & 77 \\
\hline Suplemen besi** & 19 & 63 & 11 & 37 & 22 & 73 & 8 & 27 & 41 & 68 & 19 & 32 \\
\hline
\end{tabular}

\section{Asupan vitamin A, B, C dan E}

Dari Tabel 2 tampak median asupan vitamin A pada ibu hamil sehat lebih tinggi dibanding ibu preeklampsia, masing-masing 356 (139-1065) dan 261(110-425) RE meskipun antara keduanya tidak terdapat perbedaan yang bermakna $(p=0,261)$, begitupula nilai median asupan vitamin $C$ pada ibu hamil sehat lebih tinggi bila dibanding ibu preeklampsia, yaitu 33 (7-99) dan 18 (8-60) mg namun tidak terdapat perbedaan yang bermakna antara keduanya $(p=0,554)$. Asupan vitamin $E$ antara ibu preeklampsia dan ibu hamil sehat tidak terdapat perbedaan yang bermakna antara keduanya $(p=0,574)$. Seperti halnya asupan vitamin A dan $\mathrm{C}$, terdapat perbedaan asupan beta karoten antara ibu preeklampsia dan ibu hamil sehat, namun tidak terdapat perbedaan yang bermakna antara keduanya $(p=0,114)$.

Tabel 2

Asupan Vitamin A, C, E dan Beta Karoten

\begin{tabular}{lccc}
\hline \multirow{2}{*}{ Zat gizi } & \multicolumn{2}{c}{ Ibu hamil } & \multirow{2}{*}{\begin{tabular}{c} 
Normal \\
\cline { 2 - 3 }
\end{tabular}} \\
\cline { 2 - 3 } & $\begin{array}{c}\text { Preeklamsi }\left(25^{\text {th }}-75^{\text {th }}\right) \\
\text { Med }\left(25^{\text {th }}-75^{\text {th }}\right)\end{array}$ & \\
\hline Vitamin A (RE) & $261(110-425)$ & $356(139-1065)$ & 0.261 \\
Vitamin C (mg) & $18(8-60)$ & $33(7-99)$ & 0.554 \\
Vitamin E (mg) & $5,8(2,2-18,4)$ & $6(3,7-20,1)$ & 0.574 \\
Beta Karoten $(\mathrm{mg})$ & $1567(702 .-2507)$ & $2180(846-5275)$ & 0.114 \\
\hline
\end{tabular}

\section{BAHASAN}

Dari Tabel 1 terlihat bahwa terdapat perbedaan pantangan makan antara ibu hamil dengan preeklampsia dengan ibu hamil sehat. lbu dengan preeklampsia memiliki pantang makan yang lebih banyak jika dibanding dengan ibu hamil sehat. Makanan-makanan tertentu dipantang karena ada anggapan bahwa makanan-makanan tersebut dapat membahayakan janin yang dikandungnya. Meskipun secara ekonomi beberapa makanan tersebut dapat diperoleh secara mudah, namun adanya pantangan makanan bergizi dapat membatasi asupan vitamin, selanjutnya dapat menyebabkan terjadinya defisiensi vitamin pada ibu hamil yang dapat mengakibatkan efek yang buruk pada ibu maupun janin yang dikandungnya.

Di Indonesia, juga terdapat istilah ngidam pada ibu hamil. Ngidam merupakan keinginan untuk mengkonsumsi makanan tertentu. Hasil penelitian menunjukkan bahwa persentase ngidam pada ibu dengan preeklampsia lebih rendah dibandingkan ibu hamil sehat, meskipun hasil antara keduanya tidak berbeda jauh. Makanan yang sering dikonsumsi oleh ibu hamil selama ngidam antara lain mangga muda, mangga masak, pepaya muda, serta makanan pedas dan asam.

Selain makanan pantang, ngidam, juga terdapat kebiasaan mengkonsumsi jamu 
khususnya di daerah Jawa. Persentase minum jamu pada ibu dengan preeklampsia sedikit lebih tinggi daripada ibu dengan kehamilan sehat. Pada ibu hamil terdapat kenaikan kebutuhan gizi jika dibanding dengan ibu pada umumnya. Asupan gizi yang adekuat, malabsorbsi, maupun kurangnya pengetahuan tentang gizi pada ibu menyebabkan defisiensi zat gizi pada wanita hamil ${ }^{16}$.

Dari hasil penelitian ini diketahui bahwa ibu dengan preeklampsia lebih sedikit mengonsumsi tablet besi jika dibanding dengan ibu hamil sehat. Salah satu faktor yang diyakini terkait dengan patogenesis preeklampsia adalah terjadinya disfungsi endotel ${ }^{8}$. Sel endotel yang terdapat di sekeliling lumen pembuluh darah memiliki peranan penting dalam menjaga integritas vaskuler, pengaturan koagulasi intravaskuler serta berperan dalam regulasi tonus otot polos yang dapat menyebabkan vasokonstriksi serta vasodilatasi ${ }^{17,}, 18$.

Mekanisme vasokonstriksi serta vasodilatasi dimediasi oleh beberapa substansi yang dikeluarkan oleh tubuh, salah satunya adalah NO (nitrit oksid) serta endotelin yang disekresi oleh sel endotel ${ }^{18}$. Nitrit oksid menyebabkan relaksasi dinding arteri sehingga arteri mampu berdilatasi ${ }^{17,18}$. Endotelin merupakan suatu substansi peptida bermolekul besar yang berfungsi sebagai vasokonstriktor. Endotelin akan disekresi oleh sel endotel apabila sel endotel mengalami kerusakan atau jika terdapat kerusakan pada jaringan ${ }^{18}$.

Disfungsi endotel dapat disebabkan oleh stres oksidatif yang masif dan lama. Stres oksidatif dapat disebabkan oleh terjadinya ketidakseimbangan antara oksidan (radikal bebas) dengan antioksidan di dalam tubuh. Dalam hal ini terdapat peningkatan jumlah oksidan atau terdapat penurunan jumlah antioksidan di dalam tubuh ${ }^{19}$.

Stres oksidatif merupakan fenomena yang normal selama kehamilan, namun pada kondisi preeklampsia stres oksidatif terjadi berlebihan sehingga melebihi ambang batas normal. Intervensi dini menggunakan antioksidan memungkinkan mencegah terjadinya preeklampsia dengan cara meningkatkan kadar antioksidan maternal, mencegah aktivasi $\mathrm{NAD}(\mathrm{P}) \mathrm{H}$ oksidase serta mencegah respon inflamasi. $\quad \mathrm{NAD}(\mathrm{P}) \mathrm{H}$ oksidase mampu meningkatkan stres pada vaskuler feto- plasenta, meningkatkan terbentuknya sitokin, meningkatkan sensitivitas angiotensin $\|^{20}$.

Antioksidan berperan dalam mencegah kerusakan dinding endotel dari radikal bebas dengan cara mencegah terbentuknya inisiasi permulaan rantai rantai reaksi pada radikal bebas dan memutuskan perbanyakan reaksi berantai ${ }^{19,21}$.

Beberapa penelitian tentang hubungan antara antioksidan dengan kejadian preeklampsia telah dilakukan. Pemberian suplemen vitamin $C$ dan $E$ mampu menunjukkan perbaikan indikator biokimia preeklampsia secara bermakna terhadap beberapa ibu hamil yang beresiko terkena preeklampsia22. Penelitian lain menyebutkan bahwa pemberian suplementasi vitamin $C$ dan E pada kehamilan lanjut dapat meningkatkan kadar vitamin $\mathrm{E}$ dalam plasma, namun tidak mempengaruhi kadar vitamin $\mathrm{C}$ dalam plasma. Dalam penelitian ini juga diukur frekuensi penggunaan suplemen vitamin $\mathrm{A}$ dan vitamin $\mathrm{C}$. Namun tidak terdapat perbedaan frekuensi penggunaan suplemen vitamin $A$ maupun vitamin $\mathrm{C}$ antara ibu dengan preeklampsia dan ibu hamil sehat ${ }^{23}$.

Meskipun beberapa penelitian menunjukkan adanya hubungan antara penggunaan suplemen vitamin antioksidan dengan kejadian preeklampsia, namun beberapa penelitian lainnya menyatakan tidak terdapat perbedaan yang bermakna antara keduanya. Vitamin A, C, E, dan beta karoten dikenal sebagai vitamin yang berperan sebagai antioksidan ${ }^{19,24}$. Vitamin A memiliki peran sebagai antioksidan dengan cara mendonorkan elektron dari atomnya kepada radikal bebas untuk berikatan dengan elektron yang tidak berpasangan (tunggal) dari radikal bebas tanpa menjadi radikal bebas baru24. Selain itu vitamin A juga berfungsi untuk mempertahankan stabilitas membran sel terhadap radikal bebas ${ }^{25}$. Provitamin A yakni beta karoten juga berfungsi sebagai antioksidan ketika kadar vitamin A plasma berkurang ${ }^{11}$.

Kemampuan beta karoten bertindak sebagai antioksidan terjadi akibat stabilisasi radikal bebas peroksida didalam struktur alkil terkonjugasinya ${ }^{10}$. Meskipun beta karoten merupakan prekursor vitamin $\mathrm{A}$, namun ketersediaan vitamin $A$ dan beta karoten di alam berbeda. Vitamin A banyak terdapat pada hati, mentega, susu, telur, dan produk-produk yang 
berasal dari hewani, dan beta karoten banyak terdapat pada sayur-sayuran yang berwarna kuning dan hijau tua ${ }^{19,24}$.

Penelitian ini menunjukkan nilai median asupan vitamin $\mathrm{A}$ lebih rendah pada ibu hamil dengan preeklampsia jika dibandingkan dengan ibu hamil sehat. Meskipun demikian tidak terdapat perbedaan yang bermakna antara keduanya $(p=0,261)$. Begitu pula nilai median asupan beta karoten juga lebih tinggi pada ibu dengan kehamilan sehat jika dibandingkan ibu hamil dengan preeklampsia, namun demikian tidak terdapat perbedaan yang bermakna antara keduanya $(p=0,114)$.

Kandungan vitamin A serta beta karoten yang masuk kedalam tubuh dapat dipengaruhi oleh proses pengolahan makanan. Pemasakan yang berlebihan maupun pengeringan mampu mengurangi kandungan karoten di dalam sayursayuran. Vitamin A meskipun relatif stabil, dapat rusak bila mengalami proses oksidasi ${ }^{24}$, sehingga dalam menilai asupan antioksidan, perlu diperhatikan proses pengolahan makanan yang dilakukan.

Median asupan vitamin $\mathrm{C}$ pada ibu hamil dengan preeklampsia lebih rendah jika dibandingkan dengan ibu hamil sehat dan tidak ada perbedaan yang bermakna antara keduanya $(p=0,554)$. Vitamin $C$ berfungsi sebagai antioksidan dengan mendonorkan kedua atom hidrogennya (reaksi reduksi) pada radikal bebas. Berkurangnya vitamin $\mathrm{C}$ dalam plasma berhubungan dengan kejadian hipertensi dan abnormalitas fungsi endote ${ }^{25}$. Vitamin C banyak terdapat pada jeruk, nanas, nangka, sayur-sayuran, tomat, dan lain sebagainya. Vitamin $\mathrm{C}$ merupakan vitamin yang mudah larut dalam air dan mudah hancur oleh oksidasi terutama pada suasana alkalis dan suhu panas. Sehingga makanan yang mangandung vitamin $\mathrm{C}$ paling baik jika dimasak cepat dengan sedikit air dan disajikan segera ${ }^{24}$.

Selain vitamin A, C dan beta karoten, vitamin $E$ juga dikenal sebagai vitamin yang berfungsi sebagai antioksidan. Vitamin $E$ mampu bereaksi dengan lipid peroksidase yang dibentuk dari asam lemak tak jenuh ganda yang bereaksi dengan radikal bebas. Hasil dari reaksi vitamin $E$ dengan lipid peroksidase menghasilkan komponen tokoferoksil radikal yang tidak reaktifio,19. Vitamin $E$ banyak terdapat pada minyak biji-bijian, terutama minyak benih gandum, kecambah, kuning telur, serta kacang-kacangan seperti kedelai, beras merah dan lain sebagainya ${ }^{3,7,70}$. Penelitian ini menunjukkan nilai median asupan vitamin $\mathrm{E}$ yang lebih rendah pada ibu dengan preeklampsia jika dibandingkan dengan ibu dengan kehamilan sehat serta tidak terdapat perbedaan yang bermakna antara keduanya $(p=0,574)$.

Dari hasil penelitian ini menunjukkan tidak terdapat perbedaan yang bermakna pada semua asupan vitamin. Walaupun pada Tabel 2 tampak bahwa asupan vitamin A, C, beta karoten dan $E$ lebih tinggi pada ibu hamil sehat dibanding ibu yang menderita preeklampsia. Terdapatnya perbedaan yang tidak bermakna kemungkinan disebabkan oleh jumlah sampel yang kurang besar sehingga pada penelitian ini kurang terdapat power pada penelitian. Sampel yang besar akan menambah power pada penelitian, sehingga mempersempit interval kepercayaan.

\section{SIMPULAN}

Asupan vitamin A, C, E dan beta karoten pada ibu hamil yang menderita preeklampsia lebih rendah dibanding ibu-ibu hamil sehat. Secara statistik asupan vitamin A, C, E dan beta karoten tidak ada perbedaan pada dua kelompok tersebut. Penelitian ini membuktikan bahwa Ibu hamil yang mengkonsumsi vitamin $A$, C, E dan beta karoten rendah mempunyai risiko menderita preeklamsi.

\section{UCAPAN TERIMA KASIH}

Penulis menyampaikan ucapan terima kasih yang sebesar-besarnya kepada ibu-ibu yang telah bersedia menjadi sampel dalam penelitian ini. Terima Kasih penulis sampaikan pada FK-UGM yang telah memberi dana penelitian. Tak lupa penulis menyampaikan terima kasih pula kepada CHN-RL- FK UGM dan staf yang telah membantu dalam pengumpulan dan analisis data. Semoga budi baik Bapak/lbu mendapat karunia Tuhan YME. Amin

\section{RUJUKAN}

1. Usta, I. M., dan Sibai, B. M. Pregnancy Induced Hypertension and Preeclampsia. In: Spitzer, editor. Intensive Care of The 
Fetus and Neonate. St. Louis: Mosby-Year Book, 1996

2. Sibai, B. M., Caritis, S. N., Thom, E., Klebanoff, M., McNellis, P., Rocco, I. Prevention Of Preeclampsia With Low Dose Aspirin In Healthy, Nulliparous, Pregnant Women. The National Institute of Child Health and Human Development Network of Maternal-Fetal Medicine Units. N Engl J Med, 1993, 337:67-76.

3. Dorland. Kamus Kedokteran edisi 29. Jakarta: EGC, 2002.

4. Munro, P. T. Management Of Eclampsia In The Accident And Emergency Department. J Accid Emerg Med, 2000,17:7-11.

5. Clewell, W. H. Hypertensive emergencies in pregnancy. In: Foley M.R., editor. Obstetric Intensive Care a Practical Manual. USA: WB Saunders, 1997.

6. Milne, F., Redman, C., Walker, J., Baker, P., Bradley, J., Cooper, C., et.al. The Preeclampsia Community Guideline (PRECOG): How to Screen For and Detect Onset of Pre-eclampsia in The Community. BMJ, 2005, 330:576-580.

7. Braunwald, E., Fauci, A. S., Kasper, D. L., Hauser, S. L., Longo, D. L., Jameson, J. L. Harrison's 15th Principles of Internal Medicine volume 1. USA: Mc-Graw Hill, 2001.

8. Roberts, J. M., dan Cooper, D. W. Pathogenesis and Genetics of Preeclampsia. The Lancet ,2001, 357:53-56.

9. Dekker, G. A., dan Sibai, B. M. Etiology and Pathogenesis of Preeclampsia: Current Concepts. Am J Obstet Gynecol, 1998,179:1359-1375.

10. Murray, R. K., Granner, D. K., Mayes, P. A., Rodwell, V. W. Biokimia Harper edisi $2 \underline{5}$. Jakarta: EGC, 2000.

11. Walsh, S. W. (2004). The Role of oxydative Stress and Antioksidans in Preeclampsia. http://www.contemporaryabgyn.net/be_core /content/journal/g/data/1997/0500/ g5a113.html cited Desember 2004.

12. Scholl, T. O., Leskiw, M., Chen, X., Sims, M., Stein, T. P. Oxidative Stress, Diet, and The Etiology of Preeclampsia. Am J Clin Nutr, 2005, 81(6):1390-1396.

13. Hartini, T. N. S., Winkvist, A., Lindholm, L., Stenlund, H., Persson, V., Nurdiati, D. S., dan Surjono, A. Nutrient intake and iron status of urban and rural poor without access to rice fields are affected by the emerging economic crisis: the case of pregnant Indonesian women. Eur J Clin Nutr, 2003a, 57: 654-666.

14. Hartini, T. N. S., Winkvist, A., Lindholm, L., Stenlund, H., dan Surjono, A. Food pattern during economic crisis among pregnant women in Purworejo district, Central Java. Food and Nutr Bull, 2003b, 24(3): 256-267.

15. Hartini, T. N. S., Dibley, M., Serdula, M., dan Sadjimin, T. Sistem Analisis Data Konsumsi Makanan Metode Recall 24 Jam Yang Lalu. Gizi Indonesia, 2005, 27: 35-43.

16. Ladipo, O. A. Nutrition in Pregnancy: Mineral and Vitamin Supplements. Am J Clin Nutr, 2000, 72:280S-90S.

17. Davidge, S. T., Ojimba, J., McLaughlin, M. K. Vascular Function in the Vitamin EDeprived Rat. Hypertension, 1998,31:830835.

18. Guyton dan Hall. Fisiologi Kedokteran ed.9. Jakarta: EGC, 1996

19. Murray, R. K. Harper Illustrated Biochemistry 26ed. USA: Mc-Graw Hill, 2003.

20. Raijmakers, M., Dechend, R., dan Poston, L. Oxidative Stress and Preeclampsia Rationale for Antioxidant Clinical Trials. Hypertension, 2004, 44:374-380.

21. Simanjuntak, D. H., dan Sudaryati, E. Aspek Pencegahan Radikal Bebas Melalui Antioksidan. Maj.Kedokt.Indon, 1998, 48;1:50-54.

22. Chappel, L. C., Seed, P. T., Kelly, F.J., Briley, A., Hunt, B. J., Charnock-Jones, S., Mallet, A., dan Poston, L. Vitamin $\mathrm{C}$ and $\mathrm{E}$ supplementation in Women at Risk of Preeclampsia is Associated With Changes in Indices of Oxidative Stress and Placental Function. Am J Obstet Gynecol, 2002, 187:777-784.

23. Presman, E. K., Cavanaugh, J. L., Mingione, M., Norkus, E. P., dan Woods, J. R. Effects of Maternal Antioksidant Supplementation on Maternal and Fetal Antioxidant Levels: A Randomized, Doubleblind Study. Am J Obstet Gynecol, 2003,189:6:1-15. 
24. Kartawiguna, E. Vitamin yang Dapat Berfungsi Sebagai Antioksidan. Maj.IIm.Fak.Kedokt. USAKTI, 1998,17(1): 16-26.
25. Food and Agricultural Organization of the United Nation WHO. Vitamin and Mineral Requirements in Human Nutrition 2nd. China: Sun Fung, 2004. 